\title{
Economic and ecological aspects of municipal waste management ${ }^{1}$
}

\section{Ekonomiczne i ekologiczne aspekty gospodarki odpadami komunalnymi}

\author{
* Dr Monika Gałwa-Widera, Faculty of Environmental Engineering and Bio- \\ technology, Czestochowa University of Technology, Dabrowskiego 73 St., \\ 42-201 Czesstochowa, Poland, phone: +48 3432509 17, +48 668499216 , \\ e-mail: mwidera@is.pcz.czest.pl
}

Keywords: municipal sludge, landfill, heavy metals, PAHs

Słowa kluczowe: osady komunalne, składowisko odpadów, metale ciężkie, WWA

\section{Abstract}

The Act of 14 December 2012. Waste sets out measures to protect the environment, human life and health, to prevent and reduce the negative impact on the environment and human health resulting from the production and management of waste and limiting the overall impact of resource use and improving the efficiency of such use. In this context, this study attempts to determine the model method of preventing environmental pollution by harmful substances eluted from the municipal waste.

This paper presents the research target of which were commercial landfill Sobuczynie, which was analysed by looking at contemporary legal requirements specifically set out in the Regulation of the Minister of the Environment regarding the location, construction and operation of landfills and the scope, duration and frequency, as well as the manner and conditions under which monitoring of landfills and illegal landfill in White and impact of uncontrolled spread of pollution on the environment within the "landfill".

\section{Streszczenie}

Ustawa z dnia 14 grudnia 2012r. o odpadach określa środki służące ochronie środowiska, życia i zdrowia ludzi, zapobiegajace i zmniejszajace negatywny wpływ na środowisko oraz zdrowie ludzi wynikający z wytwarzania odpadów i gospodarowania nimi oraz ograniczające ogólne skutki użytkowania zasobów i poprawiające efektywność takiego użytkowania. W kontekście pracy podjęto próbe określenia modelowego sposobu przeciwdziałania zanieczyszczeniu środowiska naturalnego substancjami szkodliwymi wymywanymi z odpadów pochodzenia komunalnego.

W pracy przedstawiono docelowe miejsca badań, którymi były komercyjne składowisko odpadów w Sobuczynie, które zostało przeanalizowane pod kątem współczesnych wymogów prawnych szczegółowo określonych w Rozporzadzeniu Ministra Środowiska dotyczące lokalizacji, budowy i prowadzenia składowisk odpadów oraz zakres, czas i czestotliwość, a także sposób i warunki prowadzenia monitoringu składowisk odpadów oraz nielegalne składowisko w Białej i wpływ niekontrolowanego rozprzestrzeniania zanieczyszczeń na środowisko przyrodnicze w obrębie „składowiska”.

\section{INTRODUCTION}

Soil is one of the main elements of the natural environment. It is an essential link in the circulation of chemical elements in nature, and the key feature of the trophic chain soil-plant-human. In natural conditions, soil acts as a buffer and prevents excessive movement of the compounds and substances of anthropogenic origin and ground-water plants. The soil is the source of the mineral component, which, in addition to solar energy, water and air, conditions the development of life, particularly in terrestrial ecosystems. As a result of urbanization, industrial development, the automotive industry and agriculture, has led man to erode the natural circulation of elements in nature. Soil as one of the elements of the biosphere was and is exposed to chemical degradation due to inflow of contaminants or loss of natural ingredients in it. Any changes in the chemical composition of soil pollution of the natural environment change the properties of biological-chemical and limit filtering and buffering action of the soil. Changes in the chemical composition of the soil on plants interact directly and indirectly with human and animals. Especially dangerous are the changes in the content of trace elements (commonly called heavy metals), because organisms respond both to their scarcity and excess, and changes in their proportions. Each soil next to the factors such as bedrock, time or direction of the process of soil formation is subject to constant change, including the anthropogenic. The soil should, therefore, be the subject of special protection, and the direction and size of changes in soil should be kept under study (monitoring). The primary function of the soil is to provide suitable amount of biomass to produce the desired quality. In the natural growth, development and yield of plants are limited by many factors, which can be represented in the system soil-climate-plant. These factors interact with each other, in accordance with the laws of nature. When these environmental factors are accompanied by human activity, there is a transformation of the environment, which can lead to degradation. The degree of contamination of soils depends not only on the dose and chemical properties of the contaminants but also on the physico-chemical characteristics of the soil cover.

Soil is an extremely complex solution is characterized by a certain system properties, which are properties may be greater or 
lesser degree - depending on the capacity of the soil buffered, modified business man. The scope and size of these changes should be examined periodically.

\section{The study area}

Sand-limestone soils in the vicinity of a landfill site in Sobuczyna were used:

They were taken directly outside the Department at a distance of 25, 50 and $100 \mathrm{~m}$ during April, May, June, July, September and October, 2013. Soil material for the study was obtained at a depth of 0-20 cm. At each distance, 10 samples were collected. At the same time and, at the same distances, same amounts of samples were also collected from green plants, depending on the season. The leaves, stems and roots of these plants were examined for the content of heavy metals such as copper, zinc, chromium, cadmium, lead, nickel and polycyclic aromatic hydrocarbons. Sand-limestone soils in the vicinity of illegal landfills in the Biala charged were: collected-directly at 25,50 and $100 \mathrm{~m}$ during April, May, June, July, September and October 2013. Soil material for the study was obtained at a depth of $0-20 \mathrm{~cm}$. At each distance, 10 samples were collected.

Also at the same time and at the same distances, the same amounts of samples were taken collected from green plants, depending on the season. The content of heavy metals and the occurrence of PAH have been studied in leaves, stems and roots of these plants.

Soil $\mathrm{pH}$ : The $\mathrm{pH}$ of the soil in the vicinity of the landfill in Sobuczyna is 6.9-7.6. In contrast, the pH of the surrounding illegal landfill in White is 7.68-7.82. pH measurement of soil samples is performed in accordance with ISO 10390:1997

Heavy metals in soil and plant samples were analysed using laboratory equipment - atomic emission spectrometer with inductively coupled plasma.

The PAHs in soil samples and plant samples were analysed using high-performance liquid chromatograph column C-18.

\section{RESULTS AND ANALYSIS}

The results of the landfill in Sobuczyna, i.e. heavy metals in soil at pH 6.9-7,6 are presented in Table 1 .

Observing the data in the table to determine the migration of individual metals in the soil in the area of commercial landfill waste and, therefore, buildings designed and protected against uncontrolled proliferation of soluble forms of pollution. Research confirms the assumption that the methods used for controlling soil are largely protective barrier. Do not isolate it completely from landfill, but significantly reduces the migration of harmful substances into the environment.

The results of research on illegal landfill in the Biala near Częstochowa heavy metals in soil at $\mathrm{pH} 7.68$ and 7.82 are presented in Table 2.

The impact of the migration of metal compounds is not only the security of the landfill but also the amount of storm water supplied to the soil. In the case of illegal garbage, metal concentrations in soils decrease with the distance from the place of storage, but much higher than the concentration within the protected area, as is the case for landfill Sobuczyna.

Overall, the comparative analysis of heavy metals in the soil allows the following conclusions:

- Highest content of heavy metals in the tested soil samples found in the month of October right by the Department, and the lowest at $100 \mathrm{~m}$ from the commercial landfill in Sobuczyna.

- Highest levels of heavy metals in soil samples observed in the month of May for illegal landfill in Biala, and the lowest level occurs in the month of July at a distance of $100 \mathrm{~m}$ from the landfill.

The results of the landfill in Sobuczyna - PAHs in soil at pH 6.9 and 7.6 are presented in Table 3 .

The highest concentration of PAHs in soil is in the month of June directly to the Department, while the lowest content is in the month of October in the area away from the facility about $100 \mathrm{~m}$.

Table 1. Contents of heavy metals in the soil around the site in Sobuczyna during the six months

\begin{tabular}{|c|c|c|c|c|c|c|c|}
\hline Distance (m) & Metals & April & May & June & July & September & October \\
\hline \multirow[t]{5}{*}{0} & $\mathrm{Zn}$ & 84.80 & 84.80 & 84.90 & 84.10 & 83.80 & 84.90 \\
\hline & $\mathrm{Cu}$ & 27.50 & 27.90 & 27.90 & 27.00 & 28.60 & 29.80 \\
\hline & $\mathrm{Pb}$ & 43.30 & 43.30 & 43.70 & 42.80 & 43.30 & 47.50 \\
\hline & $\mathrm{Ni}$ & 14.00 & 14.00 & 14.60 & 14.00 & 14.00 & 16.70 \\
\hline & Cd & 0.74 & 0.74 & 0.75 & 0.74 & 0.74 & 0.79 \\
\hline \multirow[t]{5}{*}{25} & $\mathrm{Zn}$ & 84.12 & 84.11 & 84.10 & 83.80 & 81.70 & 83.80 \\
\hline & $\mathrm{Cu}$ & 27.30 & 27.70 & 27.70 & 27.00 & 27.90 & 29.20 \\
\hline & $\mathrm{Pb}$ & 42.10 & 42.00 & 43.10 & 42.60 & 42.10 & 46.80 \\
\hline & $\mathrm{Ni}$ & 13.80 & 13.80 & 14.60 & 13.90 & 13.80 & 15.80 \\
\hline & Cd & 0.74 & 0.73 & 0.74 & 0.73 & 0.74 & 0.69 \\
\hline \multirow[t]{5}{*}{50} & $\mathrm{Zn}$ & 84.10 & 84.00 & 84.10 & 83.80 & 79.90 & 80.70 \\
\hline & $\mathrm{Cu}$ & 26.90 & 26.70 & 26.90 & 26.60 & 27.10 & 28.30 \\
\hline & $\mathrm{Pb}$ & 42.00 & 41.80 & 42.60 & 42.10 & 42.00 & 44.50 \\
\hline & $\mathrm{Ni}$ & 13.20 & 13.10 & 14.10 & 13.40 & 13.20 & 14.30 \\
\hline & $\mathrm{Cd}$ & 0.69 & 0.68 & 0.69 & 0.69 & 0.69 & 0.66 \\
\hline \multirow[t]{5}{*}{100} & $\mathrm{Zn}$ & 82.00 & 82.00 & 82.60 & 83.00 & 77.60 & 76.30 \\
\hline & $\mathrm{Cu}$ & 26.80 & 26.50 & 26.80 & 26.10 & 25.40 & 27.30 \\
\hline & $\mathrm{Pb}$ & 42.00 & 41.70 & 42.60 & 42.00 & 42.00 & 43.80 \\
\hline & $\mathrm{Ni}$ & 13.10 & 13.10 & 14.10 & 13.10 & 13.10 & 12.70 \\
\hline & $\mathrm{Cd}$ & 0.68 & 0.66 & 0.68 & 0.67 & 0.68 & 0.62 \\
\hline
\end{tabular}

Source: own research 
Table 2. Contents of heavy metals in the soil in the area of illegal landfills in Biala in the six months

\begin{tabular}{|c|c|c|c|c|c|c|c|}
\hline Distance [m] & Metals & April & May & June & July & September & October \\
\hline \multirow[t]{5}{*}{0} & $\mathrm{Zn}$ & 243.40 & 256.20 & 226.30 & 214.20 & 243.70 & 244.60 \\
\hline & $\mathrm{Cu}$ & 36.39 & 37.22 & 35.31 & 34.43 & 35.31 & 36.80 \\
\hline & $\mathrm{Pb}$ & 59.55 & 59.60 & 54.20 & 52.30 & 57.65 & 58.70 \\
\hline & $\mathrm{Ni}$ & 19.03 & 21.20 & 19.10 & 18.30 & 19.20 & 24.40 \\
\hline & Cd & 0.76 & 0.84 & 0.73 & 0.69 & 0.71 & 0.79 \\
\hline \multirow[t]{5}{*}{25} & $\mathrm{Zn}$ & 193.50 & 213.50 & 180.60 & 161.10 & 204.30 & 196.90 \\
\hline & $\mathrm{Cu}$ & 35.73 & 31.21 & 33.21 & 32.22 & 35.12 & 36.34 \\
\hline & $\mathrm{Pb}$ & 41.46 & 42.40 & 40.50 & 38.70 & 52.21 & 52.56 \\
\hline & $\mathrm{Ni}$ & 14.50 & 18.70 & 14.60 & 12.40 & 16.30 & 22.60 \\
\hline & Cd & 0.56 & 0.51 & 0.51 & 0.61 & 0.60 & 0.67 \\
\hline \multirow[t]{5}{*}{50} & $\mathrm{Zn}$ & 184.40 & 197.20 & 174.20 & 154.20 & 197.80 & 187.50 \\
\hline & $\mathrm{Cu}$ & 26.84 & 25.14 & 24.31 & 24.12 & 31.65 & 29.87 \\
\hline & $\mathrm{Pb}$ & 40.56 & 41.60 & 39.20 & 32.20 & 49.13 & 47.76 \\
\hline & $\mathrm{Ni}$ & 11.20 & 14.30 & 11.20 & 9.23 & 12.40 & 18.90 \\
\hline & $\mathrm{Cd}$ & 0.46 & 0.43 & 0.45 & 0.42 & 0.56 & 0.56 \\
\hline \multirow[t]{5}{*}{100} & $\mathrm{Zn}$ & 103.60 & 112.40 & 102.10 & 100.40 & 121.20 & 102.20 \\
\hline & $\mathrm{Cu}$ & 19.59 & 18.43 & 16.51 & 11.80 & 13.12 & 17.90 \\
\hline & $\mathrm{Pb}$ & 39.34 & 38.20 & 35.30 & 32.00 & 41.26 & 42.79 \\
\hline & $\mathbf{N i}$ & 8.74 & 9.20 & 7.73 & 5.78 & 8.60 & 9.11 \\
\hline & Cd & 0.39 & 0.41 & 0.40 & 0.36 & 0.43 & 0.41 \\
\hline
\end{tabular}

Source: own research.

The results of research on illegal landfill in the Biala near Częstochowa-PAHs in soil at $\mathrm{pH} 7.68$ and 7.82 are presented in Table 4.

On the basis of the tabular data and the observation of the graph, it can be concluded that the highest content of PAHs in soil is in the month of July directly on the illegal landfill, while the lowest content is in the month of April on the ground away from the illegal landfills by $100 \mathrm{~m}$.

Based on the analysis of PAHs in soil in Sobuczyna ( at the landfill) and in Biala it can be stated that high levels of hydrocarbons in soil samples is directly in landfills, and the lowest level observed at a distance of 100 meters from the aforementioned sites. The results of the landfill in Sobuczyna - heavy metals in plant material at pH 6.9 and 7.6 - are presented in Table 5.

The results of research on illegal landfill in the White near Częstochowa - heavy metals in plant material at a pH 7.68 and 7.82 are presented in Table 6.

As in the case of the soil, the plant material's metal content proportionally decreases with increasing distance from landfill sites. Because green plants have the ability to accumulate metals in their tissues, very significant impact on their quality is protected against leaching landfills available forms of these compounds. It can be observed that within the storage space, illegal content is in some cases even by one order higher than for a commercial installation. Overall, the comparative analysis of heavy metals in plant material allows the following conclusions:
- Highest content of heavy metals in the tested samples of plant states right on the Department, and the lowest at $100 \mathrm{~m}$ from the commercial landfill in Sobuczyna.

- Highest levels of heavy metals in plant samples is observed directly on an illegal landfill in Biala, while the lowest level is 100 meters from the landfill.

PAHs in plants both in the vicinity of the site in Sobuczyna commercial as well as in the area of illegal landfills in the White stands at approximately $160 \mu \mathrm{M} / \mathrm{kg} \mathrm{DM}$.

\section{CONCLUSIONS}

The essence of research was the soil and plant material obtained from the area of commercial landfill Sobuczyna and illegal landfills in the Biala near Czestochowa. Comparing the results of research related to the impact of municipal waste and contained in them heavy metals and polycyclic aromatic hydrocarbons on the quality of both soil and plant material begs the conclusion that a much higher level of harmful substances observed in samples of soil and plants from an illegal landfill in White, which confirms the previously established theory. Clearly proves that the illegal landfill is hazardous to both the environment and the health and life of humans. The reason for this may be that these wastes are unsorted, e.g. you can find it there either inert waste other than inert and dangerous. Also backing the illegal landfill is not secured by

Table 3. The content of PAHs in the soil around the site in Sobuczynan in the six months

\begin{tabular}{|c|c|c|c|c|c|c|c|}
\hline \multirow{2}{*}{ Distance [m] } & \multicolumn{7}{|c|}{ PAHs in the soil in the vicinity of the site in Sobuczyna } \\
\cline { 2 - 7 } & April & May & June & July & September & October \\
\hline $\mathbf{0}$ & 586 & 571 & 595 & 558 & 563 & 498 \\
\hline $\mathbf{2 5}$ & 584 & 584 & 591 & 567 & 547 & 512 \\
\hline $\mathbf{5 0}$ & 497 & 511 & 586 & 542 & 556 & 496 \\
\hline $\mathbf{1 0 0}$ & 492 & 494 & 498 & 521 & 489 & 488 \\
\hline
\end{tabular}

Source: own research. 
Table 4. PAH content in the soil in the area of illegal landfills in Biala in the six months

\begin{tabular}{|c|c|c|c|c|c|c|}
\hline \multirow{2}{*}{ Distance [m] } & \multicolumn{6}{|c|}{ PAHs in the soil in the vicinity of the site in Sobuczyna } \\
\hline & April & May & June & July & September & October \\
\hline 0 & 774 & 777 & 758 & 787 & 765 & 732 \\
\hline 25 & 776 & 762 & 765 & 778 & 743 & 733 \\
\hline 50 & 732 & 763 & 778 & 734 & 746 & 723 \\
\hline 100 & 690 & 778 & 769 & 756 & 743 & 711 \\
\hline
\end{tabular}

Source: own research.

any collateral, and thus may even result in contamination of the environment. This threat is related to the fulfilment of the unsealed pits, through contamination of groundwater and surface water, the impact of odorous, bacteriological contamination threat.

Preventing uncontrolled pollution and reducing the negative impact on the environment and human health resulting from the production and management of waste is appropriate to comply with the rules and requirements applicable to commercial landfills. Hence, the great importance of the Act of 14 December 2012. Waste, as it determines the measures to protect the environment, human life and health, reducing the overall impact of resource use and improving the efficiency of such use, preventing and reducing the negative impact. To define a model way of preventing environmental pollution by harmful substances eluted from the municipal waste, the ideal solution would be to use a commercial landfill monitoring, which will provide the necessary information related to the activities to protect the environment. In conclusion, it is of great importance: segregation of waste, reuse of materials, recycling, waste disinfected with lime chlorinated and then overwhelm their material inertia, the gateway isotopic entry positions for the detection of radioactive substances, the inspection station to verify the quality and consistency of norm entering the landfill wash for cleaning and disinfecting the wheels and chassis of vehicles leaving the landfill leachate treatment plant operating on the principle of reverse osmosis, accommodation of selective storage of recyclable materials, construction requirements taking into account the hydrogeological conditions, requirements for systems solutions leachate drainage, geoisolation using natural geological barrier and sealing surface and side walls (supplemented by a synthetic insulation, designed in a way that takes into account the composition of the waste and geotechnical conditions of storage) requirements for installation of drainage systems solutions landfill gas (purified and used them for energy purposes), methods of securing the protective green belts (consisting of trees and shrubs limiting the emission of: odour and dust, spreading rain through wind, noise and traffic impacts of animals, the formation of aerosols and fire), and land reclamation. Waste separation has both environmental and economic benefits, as municipal wastes are rich in substances of biological origin, which constitute one of the major nuisances in large clusters, and at the same time are the causes of the degradation of agricultural land. Restoration of the environment of these substances should be the goal soil economic and environmental. Therefore, the current and projected composition of municipal waste makes them potential resources, insufficiently used economically. Selective collection and comprehensive utilization of municipal waste requires proper city structure and technical equipment, and so is most advanced in developed countries.

Table 5. Contents of heavy metals in the plant material in the vicinity of the site Sobuczyna

\begin{tabular}{|c|c|c|c|c|c|c|c|}
\hline Distance [m] & Metals & April & May & June & July & September & October \\
\hline \multirow[t]{5}{*}{0} & $\mathrm{Zn}$ & 32.13 & 33.45 & 32.65 & 32.64 & 31.76 & 31.34 \\
\hline & $\mathrm{Cu}$ & 7.30 & 7.34 & 7.33 & 7.23 & 7.30 & 7.32 \\
\hline & $\mathrm{Pb}$ & 6.89 & 7.01 & 43.70 & 42.80 & 43.30 & 47.50 \\
\hline & $\mathrm{Ni}$ & 3.13 & 4.06 & 4.61 & 4.32 & 4.21 & 3.71 \\
\hline & $\mathrm{Cd}$ & 2.60 & 3.45 & 3.41 & 3.45 & 3.12 & 3.71 \\
\hline \multirow[t]{5}{*}{25} & $\mathrm{Zn}$ & 31.23 & 33.24 & 32.40 & 32.43 & 31.45 & 31.21 \\
\hline & $\mathrm{Cu}$ & 7.30 & 7.30 & 7.32 & 7.22 & 7.28 & 6.89 \\
\hline & $\mathrm{Pb}$ & 6.78 & 6.98 & 43.10 & 42.60 & 42.10 & 46.80 \\
\hline & $\mathrm{Ni}$ & 3.08 & 3.81 & 4.58 & 3.99 & 3.98 & 3.43 \\
\hline & Cd & 2.56 & 3.22 & 3.32 & 3.43 & 3.11 & 3.43 \\
\hline \multirow[t]{5}{*}{50} & $\mathrm{Zn}$ & 29.22 & 32.32 & 31.87 & 31.81 & 31.11 & 31.19 \\
\hline & $\mathrm{Cu}$ & 7.21 & 7.21 & 7.26 & 7.22 & 7.28 & 6.45 \\
\hline & $\mathrm{Pb}$ & 6.65 & 6.71 & 42.60 & 42.10 & 42.00 & 44.50 \\
\hline & $\mathrm{Ni}$ & 3.12 & 3.17 & 4.23 & 3.76 & 3.58 & 3.31 \\
\hline & Cd & 2.55 & 3.12 & 3.31 & 3.12 & 3.03 & 3.31 \\
\hline \multirow[t]{5}{*}{100} & $\mathrm{Zn}$ & 27.28 & 32.21 & 31.65 & 31.60 & 31.09 & 31.11 \\
\hline & $\mathrm{Cu}$ & 7.11 & 7.21 & 7.26 & 7.21 & 7.26 & 6.45 \\
\hline & $\mathrm{Pb}$ & 6.13 & 6.71 & 42.60 & 42.00 & 42.00 & 43.80 \\
\hline & $\mathrm{Ni}$ & 3.12 & 3.17 & 4.21 & 3.77 & 3.21 & 2.98 \\
\hline & $\mathrm{Cd}$ & 2.55 & 3.09 & 3.12 & 3.01 & 2.98 & 2.98 \\
\hline
\end{tabular}

Source: own research. 
Table 6. Contents of heavy metals in the plant material in the area of illegal landfills in the Biala

\begin{tabular}{|c|c|c|c|c|c|c|c|}
\hline Distance [m] & Metals & April & May & June & July & September & October \\
\hline \multirow[t]{5}{*}{0} & $\mathrm{Zn}$ & 174.1 & 172.5 & 172.5 & 173.1 & 173.6 & 174.1 \\
\hline & $\mathrm{Cu}$ & 21.2 & 21.3 & 20.4 & 20.3 & 21.2 & 21.2 \\
\hline & $\mathrm{Pb}$ & 47.5 & 41.3 & 41.3 & 42.8 & 43.3 & 47.5 \\
\hline & $\mathrm{Ni}$ & 6.34 & 6.21 & 6.21 & 5.65 & 5.45 & 6.34 \\
\hline & $\mathrm{Cd}$ & 23.3 & 23.1 & 23.1 & 23 & 23.2 & 23.3 \\
\hline \multirow[t]{5}{*}{25} & $\mathrm{Zn}$ & 167.3 & 171.2 & 171.3 & 169.4 & 168.3 & 168.3 \\
\hline & $\mathrm{Cu}$ & 20.2 & 21.3 & 20.2 & 20.0 & 21.1 & 20.2 \\
\hline & $\mathrm{Pb}$ & 46.8 & 40.3 & 40.3 & 42.6 & 42.1 & 46.8 \\
\hline & $\mathrm{Ni}$ & 6.21 & 6.20 & 6.21 & 5.34 & 5.21 & 6.21 \\
\hline & $\mathrm{Cd}$ & 22.8 & 22.7 & 21.2 & 18.8 & 19.4 & 22.3 \\
\hline \multirow[t]{5}{*}{50} & $\mathrm{Zn}$ & 163.3 & 169.3 & 168.3 & 164.3 & 165.2 & 161.3 \\
\hline & $\mathrm{Cu}$ & 20.1 & 20.5 & 20.0 & 20.0 & 20.6 & 20.0 \\
\hline & $\mathrm{Pb}$ & 43.5 & 37.9 & 38.8 & 42.1 & 42.0 & 44.5 \\
\hline & $\mathrm{Ni}$ & 6.21 & 6.10 & 6.10 & 4.89 & 5.10 & 6.20 \\
\hline & $\mathrm{Cd}$ & 22.3 & 22.4 & 21 & 18.1 & 18.9 & 22.1 \\
\hline \multirow[t]{5}{*}{100} & $\mathrm{Zn}$ & 161.8 & 167.5 & 166.9 & 161.6 & 163.0 & 161.1 \\
\hline & $\mathrm{Cu}$ & 20.0 & 19.8 & 19.8 & 19.8 & 20.2 & 20.0 \\
\hline & $\mathrm{Pb}$ & 43.1 & 37.3 & 37.8 & 42.0 & 42.0 & 43.8 \\
\hline & $\mathrm{Ni}$ & 5.98 & 5.87 & 5.87 & 4.45 & 5.10 & 5.99 \\
\hline & $\mathrm{Cd}$ & 21.7 & 11.8 & 19.7 & 17.8 & 18.8 & 21.7 \\
\hline
\end{tabular}

Source: own research.

\section{REFERENCES AND LEGAL ACTS}

DRZEWICZ P. 2008. Wielopierścieniowe węglowodory aromatyczne - występowanie i oznaczenie. Raporty IChTJ. Seria B nr 4/2008. Instytut Chemii i Techniki Jądrowej, Warszawa.

GRUSZECKA A. 2011. Badane metale ciężkie w wodach i osadach rzecznych oraz glebach w otoczeniu składowisk odpadów górniczych i hutniczych w Bukowinie ( Polska) i Mansfeld (Niemcy). Wydawnictwa AGH, Kraków.

KLIMKOWICZ-PAWLAS A. 2009. Oddziaływanie wielopierścieniowych węglowodorów aromatycznych na siedliskową funkcję gleby, Wydawnictwa IUNG-PIB, Puławy.

Ustawa z dnia 14 grudnia 2012 r. o odpadach. (Dz.U. 2013 Nr. 0. poz. 21).

Ustawa z dnia 27 kwietnia 2001 r. o odpadach. (Dz. U. z 2001r. Nr 62. poz. 628).

Ustawa z dnia 27 kwietnia 2001 r. Prawo ochrony środowiska. (Dz. U. z 2001r. Nr. 62. poz. 627).

WOLAK W., LEBODA R., HUDNICKI Z. 1995. Metale ciężkie w środowisku i ich analiza, PIOŚ, Chełm. 